Volume 3 Issue 10 (September 2021) PP. 74-85

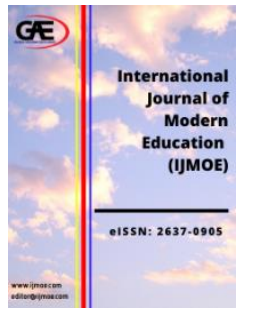

\author{
INTERNATIONAL JOURNAL OF \\ MODERN EDUCATION \\ (IJMOE) \\ $\underline{\text { www.ijmoe.com }}$
}

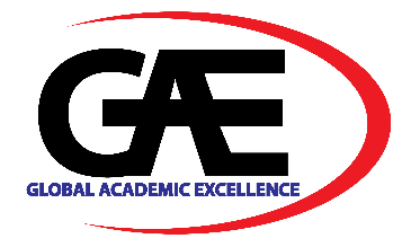

\title{
THE TALE OF THE TWO LANGUAGES: THE QUEST IN UNDERSTANDING STUDENTS TOWARD ORAL COMMUNICATION
}

\author{
Nurul Nazira Hamzah ${ }^{*}$, Nor Ain Manap ${ }^{2}$ \\ 1 Pusat Penataran Ilmu dan Bahasa, Universiti Malaysia Sabah, Malaysia \\ Email: nazira86@ums.edu.my \\ 2 Pusat Penataran Ilmu dan Bahasa, Universiti Malaysia Sabah, Malaysia \\ Email: ain@ums.edu.my \\ * Corresponding Author
}

\section{Article Info:}

Article history:

Received date: 02.05.2021

Revised date: 15.05 .2021

Accepted date: 18.08.2021

Published date: 05.09.2021

\section{To cite this document:}

Hamzah, N. N., \& Manap, N. A. (2021). The Tale Of The Two Languages: The Quest In Understanding Students Toward Oral Communication. International Journal of Modern Education, 3(10), 74-85.

DOI: $10.35631 / \mathrm{IJMOE.310006}$

This work is licensed under CC BY 4.0

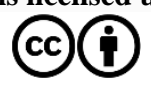

\begin{abstract}
:
This study investigates how students with basic English and Arabic language proficiency from the foreign language perceive their oral communication challenges in completing their oral project for Oral Communication in English and Arabic Language Level 3 - Interviewing Native/Second language speakers in the target language. Qualitative research using the case study method was adopted. A total of 74 Arabic students \& English were taken for this study is on purposeful sampling. Students were required to present a short reflective journal on their view of their project at the end of the semester to the teacherresearcher. Major findings indicate that students generally held a positive view towards the idea of approaching native speakers to practice the languages. Finally, to maximize the potential of the students, it is suggested that a need analysis should be conducted at the beginning of the semester to understand the needs and preferences of students when using the languages orally both inside and outside the campus, formal and informal use. Teachers should also try to utilize the potential of the mixed-ability group to enhance peer learning and sharing.
\end{abstract}

Keywords:

Speaking Skill, Interview, English, Arabic, Oral Communication 




Volume 3 Issue 10 (September 2021) PP. 74-85

DOI: 10.35631/IJMOE.310006

\section{Introduction}

Malaysian tertiary graduates have been known for their knowledgeable academic achievement especially in industry related. However, most of them are lack communication skills as portrayed by the media about the unemployment of graduates. According to the Malaysian Unemployment Rate statistic between 1997-2017, 3.28 percent were reported and one of the reasons for unemployment is lack of soft skills. Communication skills indisputably smooth the progress of a myriad of life opportunities. Consequently, The Malaysia Education Blueprint (2015:6) believes that the higher institution, both private and public held liable in ensuring the courses offered can bind "graduates with directly employable skills, values, and behaviors that match industry demand". Universiti Malaysia Sabah, particularly Pusat Penataran Ilmu dan Bahasa which caters to languages around the world is no exceptional; particularly English and foreign language such as Arabic.

It is manifest that there is a vital need for graduates to master skills that are job creditable that include critical thinking and communication skills, English language proficiency or foreign language that are one of the essential. It is also mentioned in the Malaysia Education Blueprint (2015) that employers found that graduates that attended interviews showed poor communication in English or foreign language. Therefore, the purpose of the present study was to explore the perceptions of students with low/weak proficiency feel about completing their final project for UB00202 Oral Communication in English-Interviewing Native/Second language speakers and UA00302 Arabic Basic for level 3 in the target language as effective communication skills.

\section{Literature Review}

Communication is a vital part of learning. Speaking is the productive part of oral English in communication while listening is its receptive part (Celce Murcia, 1989). According to Husain, F (2015) a study conducted by Robles (2012) identified communication skills as the top 10 soft skills perceived as the most important by 49 business companies and these skills can be promoted by educators in their curriculum to improve the employability of graduates. The literature has also identified oral communication skills as the most pertinent and predominantly used at the workplace (Mohamad Zasfirul Zainal Abidin, 2010; Stapa et al., 2008; Luna, 2004). Therefore, to prepare them for the real world. Oral activities that are authentic necessitate enhancing their capability in familiarizing communication to a real setting.

The level of use of the Arabic language among the students at the five IPTA in Malaysia is low. This happened perhaps due to external and internal factors such as feeling embarrassed, unconfident, anxious, and uninspired (Abdul Halim Mohammad, 2009). In learning a foreign language as an added value to students, lacking vocabulary and difficulty to speak in the Arabic language has put up the student ability to involve in speaking activities. (Nadwah and Nadhilah, 2014)

The aim or objective of learning a foreign language at the Malaysian Educational Institution to provide the students with communication skills difficult-to-be-achieved in the event of psychological barriers and from the attitude among them (Azman and Goh, 2010). The suggestion is using the collecting words and sentences, consolidation, and approach of application should be used in learning and teaching proses to enhance the achievement of speaking skills among the students. (Rosnih Samah et al., 2013) 


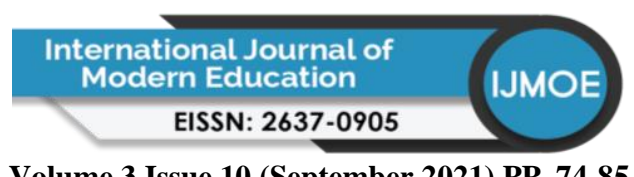

Volume 3 Issue 10 (September 2021) PP. 74-85

DOI: 10.35631/IJMOE.310006

To make them understand the real world, reflection is introduced. Yancey (1998) said that "[i]f we don't ask our students to [reflect on] their work- a process based on internal factors and criteria - they are likely to [remain] dependent on external rewards, now knowing where to begin to consider their performance" (p. 14). Additionally, as mentioned by McCormick, Dimmitt, \& Sullivan, (2013), students who are exposed to metacognitive activities, such as written self-reflection, tend to be more engaged in their schoolwork as well as maintain their academic achievement. Reflection could be seen as a type of self-evaluation on students' actual ability to evaluate their work. This study reflects on students' perceived effort and gauges their overall performance of the task at hand. Therefore, the reflection is used as a tool for improved metacognitive practices to effectively improve their communication, motivation, and performance.

The reflection in learning a foreign language also so important. According to Maskanah, Badri, and Mohd Feham (2013), they found that students ' perception of learning of Arabic language is very positive but depends on the syllabus or reference for communication whether the need for the work environment. Awatif, Ku Fatahiyah and Hairun (t.th:) expresses the students' perception of learning and teaching very high in Arabic but should look at three main support cluster either lecturers, students, or institutions.

According to Mohd Shahrizal et al., (2017) he said the early perception of non-Muslim students for the Arabic language courses was negative. But eventually, their perception changed to positive based on several aspects such as teacher teaching strategies and learning purposes. The other study also founds the perceptions of the Malay good Arabic speakers different than the Malay poor Arabic speakers because they thought Arabic speaking skills are not important for the Malay learners except as a basic skill. But finally, the result also found to be successful as Arabic speaking skill requires various strategies and influenced by the student's perception (Sueraya et al., 2010).

Based on research conducted by Mountford and Rogers (1996) on the use of individual and group reflection as an instrument for effective learning for nurses claimed that 6 key factors influence positive education outcomes including academic self-concept, task awareness views of knowledge, the influence of knowledge on behavior, writing as a learning activity, and generating knowledge by reflecting in and on assessment with discussion. (p. 1127). These key factors not only emphasize the power of reflection as an academic learning tool, but also its ability to fundamentally change the way students think and recognize their effort, motivation, and ability to complete tasks. As discussed by Rusche and Jason (2011), "giving students an opportunity to "write it out not only can alleviate some frustration but can significantly deepen their grasp on the material, even when they do not like it or agree with it" (p. 346). They also said that self-reflection is real in interrogating students' belief and perspectives by acknowledging how their influences the people around them. (pp. 339-340). Colley, Bilics, and Lerch (2012) took a correspondingly positive outlook concerning the power and importance of metacognitive thinking as developed by reflection as a "lifelong learning takes place through reflection.

\section{The Problem}

The quandary faced by Malaysian students is the inability to communicate in English positively. According to McCroskey (1984), many students even at higher levels of study experience some level of fear and anxiety when asked to communicate, especially in public. 


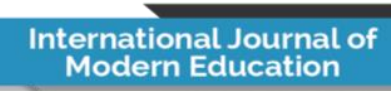

EISSN: 2637-0905

Volume 3 Issue 10 (September 2021) PP. 74-85

DOI: 10.35631/IJMOE.310006

This feeling of discomfort when communicating is called communication apprehension. It can be stressful for them when they are expected to speak a second language. Therefore, students are unable to perform well in speaking skills, and they fail to communicate well. A study of students taking Arabic Language Skills Course, at International Islamic University Malaysia (IIUM), also found that $70 \%$ of students could not effectively participate in class discussions due to their poor proficiency in Arabic (Nadwah and Nadhilah, 2014).

Most teachers are at sea as to how to provide students with opportunities to develop their communicative skills and this proves a challenge even in the higher institutions of learning with the current iCGPA implementation into the curriculum. Although the English language is the medium of instruction at the university level, many students (including final year graduates) still struggle to communicate in English for academic purposes (Mustapha, 2010).

\section{Research Aims and Objectives}

This study aims to investigate proficiency ESL students' perceptions towards the implementation of Interview Project in UB00202 Oral Communication course and UA00302 Arabic Basic for level 3.

The objectives of this study are to;

1. Identify challenges faced Before/ During and after Interview Project

2. Investigate students' perceptions of the Interview Project Effect Interview Project towards students'

\section{Research Questions}

The research questions in this study are as follows:

1. What are the challenges faced by students when completing the Final Interview Project?

2. What are students' perceptions of the Interview Project?

3. What is the effect interview project on students?

\section{Methodology}

This study employed a case study design with a qualitative approach. A case study is particularly useful in my study on rare or complex phenomena such as oral communication failures in learning ESL. The focus of the case study is upon a particular unit and that is the case. The social unit being studied defines the case study, whether it is a person, a program, a company, a situation, or whatever (Maylor and Blackmon, 2005). The strength of a case study is that it can take an example on an activity - 'an instance in action' -and use multiple methods and data sources to explore it and interrogate it and thus it can achieve a rich description of a phenomenon (Stark and Torrance, 2005). Neuman (1997) states that a qualitative researcher may use a case study approach where he/she might gather a large amount of information on one or a few cases, go into greater depth, and get more details on cases being examined. The case study researcher goes for data analysis differently in comparison to quantitative researchers. So, it is qualitative due to the data needed to answer the Research Questions posed in this study.

\section{Sampling}

A total of 74 students were used as respondents. All respondents were around the age of 20-25 and are studying English Language Level 2 (Oral Communication) and Arabic Basic Level 3. 


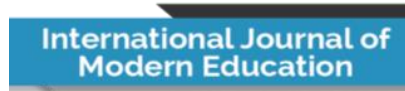

EISSN: 2637-0905

Volume 3 Issue 10 (September 2021) PP. 74-85

DOI: 10.35631/IJMOE.310006

Most of them obtained either band 1, 2, or lower band 3 for English students and band 4, 5 or 6 for Arabic students, in the Malaysian University English Test. About $60 \%$ of the class obtained a lower band 3,30\% band 2, and 10\% band 1; and has average proficiency of the language. In addition to random sampling schemes, out of seven purposive sampling schemes presented by Onwuegbuzie and Collins (2007), nested sampling is relevant in my case study to obtain representativeness (Sankoff, 1971). Both languages were selected via nested sampling as it is available to the teacher-researcher. The participants were a group of year one and two undergraduate students with multiple course backgrounds at Universiti Malaysia Sabah.

\section{Case Study Step-by-Step Procedure}

There were six steps procedure or protocol embraced in this case study, they are as follows:

a. The research started with the problem - the study question. The problem can be defined as a discrepancy between an initial state (what we have) and a final state (what we want to have) and is realized in the objectives.

b. The objectives and the propositions were made clear.

c. The next step involved defining the unit of analysis and then data collection. The data collection utilized four qualitative methods. Data come for various sources and depending on the problem and objectives, it will be collected qualitatively.

d. Once collected, the data was analyzed qualitatively. The data collected qualitatively.

e. In the next step, linking this categories analysis in a logical way was used to link our results to the study objectives and/or propositions.

f. Finally, based on the aspects discussed at point "e", conclusions and discussions led to the interpretation of findings in the particular context and in the larger context of the scientific literature on the topic.

\section{Results and Discussion}

The data from the reflection were analyzed and students' responses data were grouped based on pre-interview (a) issues and challenges; post-interview (b) consequential value in academic motivation, and (c) consequential value in affective (emotional) motivation. A summary and analysis of specific detail for each of the indicators are presented below.

\section{Question 1}

\section{What are The Challenges of the Interview Project?}

\section{Issues And Challenges Faced During The Project Interview.}

The challenges faced by the students were related to issues concerning the journey of the project, including before, during, and after the interview. Generally, the students believed that they were frightened by the idea of approaching foreigners. Apart from being nervous, students' motivation has deteriorated when some respondents refused to be interviewed that resulted in despair. Feedback from English students can be seen below.

“.... before conducting the project, I would tend to avoid foreigners ...”(S1)

“approaching foreigners who spoke English was a huge problem...I am not good in approaching people .... i tend to shutter and get nervous. "'(S4)

"I felt so hard until I want to give up..."(S8) 
Volume 3 Issue 10 (September 2021) PP. 74-85

"all the respondents refuse to be interview...

"I had no idea to talk the person in English."(S22)

"...I felt nervous and afraid when asking them to do interview...I was really scared..."(S23)

“...it's very hard to approach ... they wouldn't give cooperation ... I almost give up because we got rejected many times. Lack of communication skills...”(S24)

\section{And feedback from Arabic students can be seen below;}

“...not confident to speak in Arabic, but we've tried very hard until we can delivered what we want..." (G1)

“...tried hard to speak in Arabic although we have no any basic and not fluent ..."(G2)

“...don't have any transport to go to the interview place..." (G3)

“...have a little basic in Arabic but still not fluent to speak...” (G4)

“...less skills in Arabic and had limited ability to speak fluently...” (G5)

“...lacking in usage of Arabic grammar ...”(G7)

“...not mastering Arabic language..."(G8)

\section{Question 2}

\section{What are Students' Perceptions of The Final Interview Project?}

Reflection instruments were used to determine a positive or negative influence on students' academic motivation and affective motivation to complete assignments based on their responses. The role of metacognition is articulate found in the challenges faced. Metacognition is "knowledge or beliefs about factors affecting one's cognitive activities; also, a reflection on a monitoring of one's cognitive processes, such as memory or comprehension" (ERIC Descriptors: 190). It is simply about the awareness of a particular learner about the improvement or performance in cognitive and emotional progress by self-assessment. Responses relayed on academic motivation and self-efficacy as following.

\section{Consequential Value in Academic Motivation}

\section{Communication}

The communication referred to the imparting or exchanging of information by speaking, writing, or using a two-way process of reaching mutual understanding, in which participants not only exchange (encode-decode) information, news, ideas, and feelings but also create and share meaning. In general, communication is an act of connecting people or places (Lee.D, Brosziewski. A, 2009). The students mentioned how the project, the course, 
Volume 3 Issue 10 (September 2021) PP. 74-85

DOI: 10.35631/IJMOE.310006

and their peers help them cope with communication in the target language. Comments as mentioned in the following extracts:

"...I able to learn the proper way to communicate with foreigners... this is the first time to fully use English language in communicating... " (S2)

“...I have been able to communicate in English." (S6)

“...my friends and this subject teach me on how to communicate with other." (S7)

“... this subject taught us about communicating.” (S8)

\section{Comments from Arabic students as mentioned in the following extracts:}

"...feel the new experience to speak in Arabic with students from different universities..."(G3)

“...new experience to talk with Malaysian students in Arabic from Egypt ... " (G11 \& G9)

“... able to learn something new and gain knowledge and make a new friend with Arabic-speaking friends." (G10)

\section{Improvement}

Some students have positive aspects of improvement in their oral skills; and the experience and self-consciousness of using English and Arabic fully while communicating. The role of metacognition arose when they reflect on how the project encourage them realized their capability in using English and Arabic outside the classroom in a real setting. Due to the setting, it was said to be a great platform to practice their communication skills. From English students:

“...the interview project is a great platform in helping one to improve their English communicating skill.” (S1)

"this is the first time I fully use English language in communicating... and had gained more interest in English language." (S2)

“...I had learnt how to approach people...I also learnt on how to respond to people without referring to script... and I actually realize I have the ability to speak in English." (S3)

"can help improve the way communicating in English...improving patience within ourselves..." (S7)

"...I can improve my level of communication with tourists and strangers besides acquiring knowledge indirectly...” (S9) 
Volume 3 Issue 10 (September 2021) PP. 74-85 DOI: 10.35631/IJMOE.310006

From Arabic students:

"...increase confidence to speak Arabic even though it is baseless and less fluent..." $(G 1)$

“...try my best to speak in Arabic...” (G5)

“...can learn and apply the Arabic grammar through the Arabic conversation..." (G6)

“...we understand the use of grammar better than before ..." (G8)

\section{Cooperation}

Factors facilitating cooperation are individual motivation and the desire for academic development. It has to have mutual trust between members of the group. The students indicated that audience analysis, persuasion techniques, and group communication in problem-solving were important in teamwork. The following extracts demonstrate the perceived relevance:

"collaboration among the members is very important and has helped the production of this project." (S7)

“...I learned how the teamwork meaning which mean they give cooperation...” (S8)

“...taught me team spirit and cooperation to complete the project." (S9)

"we could cooperate each other and try solve problems..." (S10)

"with the project I learned cooperation with my group and tighten our bonding." (S20)

"responsibility and cooperation are really important in a group." (S23)

Extracts demonstrate the perceived relevance from Arabic students:

“...responsibility to find the right respondents who are willing to be interviewed..." (G3)

“...working together until we can overcome video editing problems and producing the best video..." (G4)

"...be patient, understand and wait for the respondents to be ready and have the right time for the interview..." (G5)

“...can perform and accomplish all the task excellent..." (G6)

“...cooperating to search other respondents as a result of changes from the original respondent..." (G7)

“...strengthen the relationships with the team members...” (G8) 
Volume 3 Issue 10 (September 2021) PP. 74-85

“...work together to find the right place for Interview...” (G9)

“...responsibility to find the fluent speakers and person who can speak in Arabic..." (G10)

“...trying hard to find the right time to do the interview project together...” (G11)

\section{Consequential Value in Affective Motivation}

\section{Confidence}

Confidence referred to a feeling or belief that you can do something well or succeed at something (Oxford dictionary, 2010). In this study, the interview project incorporates factors affecting self-assurance such as culture, custom, social persuasion, experience (failure and success) in the process; therefore, common physiological signs of distress such as fear, panic, and nausea. However, these signs were nowhere to be found. Students mentioned that the project helps them cope with fear by generating confidence. They were braver hence it increased the level of self-confidence.

"this project is a great platform to gain confidence... the biggest impact this project had affected me is the increase in confidence level." (S1)

“...I feel more relieved and confident in speaking...” (S2)

“...after going through this project, I had gained a higher confident level compare to before." (S4)

"can build self confidence in communicating with tourist/visitors." (S5)

"help to provide confidence when speaking in English especially dealing with tourists whose first language is English.” (S7)

"this is a great experience for me, because this makes me become more confidence when talking with someone..." (S15)

"we manage to be more confident to talk with people in English." (S18)

“actually, I don't have confidence talk in English ... but with this project I learned how to be confident..." (S20)

\section{From Arabic Students:}

“...lay the edge of felling ashamed and we've tried very to speak until we can deliver what we want..." (G1)

"...push our self to speak in Arabic although we have not any basic and not fluent..." $(G 2)$

“...confident to apply the Arabic grammar through the Arabic conversation..." (G6) 
Volume 3 Issue 10 (September 2021) PP. 74-85

DOI: 10.35631/IJMOE.310006

"...help to understand the usage of grammar better than before and more confident to speak Arabic..." (G8)

\section{Enjoyment}

According to the Merriam dictionary, enjoyment means a feeling of pleasure caused by doing or experiencing something one likes or the condition of having and using something good and pleasant. It is also appeared naturally without being a force. By giving something invigorating, they will involve themselves in speaking without being compelled. The elements of comfort and confidence permitted them to have fun and use the target language without being vulnerable. Data is confirmed the reflection data by saying that they feel happy, fun, enjoyable, great experience, encouraging, confident and brave when completing their project. Evidence below:

“...i had the opportunity to meet with many foreigners. " (S4)

"have experience in how to greet strangers in the right and proper way" (S5)

“...through my experience speaking with foreigners it so fun and they are easy...” (S6)

“...this project also gives me some memorable thing that I never experienced before..." (S8)

“...it was enjoyable to be in this wonderful group...” (S14)

"this is a great experience for me." (S15)

"I'm very happy for our project..." (S24)

\section{From Arabic Students:}

“...a great experience to speak in Arabic with students from different local universities..."(G3)

“...great experience of working together to overcome video editing problems and producing the best video..." (G4 \& G5)

“... happy because we able to perform and complete this task well and applies what has been learned... "(G6)

“...gain new experience and increase our understanding in Arabi language...” (G7)

"...strengthen the relationships and memorable thing with the team member, new experience to prepare the interview questions in Arabic and great experience providing scripts in words to video editing applications ..." (G8)

“...great experience of using video calls to Malaysian students in Arabic from Egypt ..." (G9) 


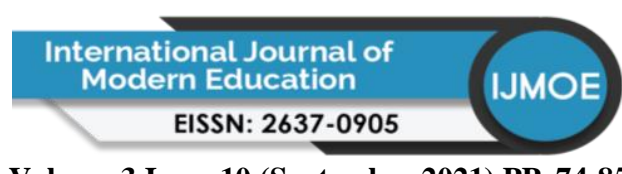

Volume 3 Issue 10 (September 2021) PP. 74-85

DOI: 10.35631/IJMOE.310006

“...we are happy to make a new friends with Arabic-speaking friends ...” (G10)

“...a great experience to talk with Malaysian students in Arabic from Egypt ... " (G11)

All in all, the students had a very positive attitude towards the project. They were positive about the benefits and usefulness of the real-world practice in the future undertaking. They agreed that the project helped them to interact with others better. The studies have not found the negative side of impacts project from students. Average students give a positive comment.

\section{Conclusion}

In summary, the findings show that the students perceived that they had better communication skills in the course. They also learn a lot of new technology and video editing application for this Interview Project. This study contributes to a better understanding of the range of student experiences, their views, and the challenges that students face in meeting and using the target language outside the classroom. It will also provide valuable information for designing an oral communication course that meets the needs of students.

This study has established that interviewing foreigners encouraged the use of language and motivates students cognitively and emotionally. The big question however remains whether the participants will lead to; increase proficiency and the rate of acquisition. As such it is recommended that future studies concentrate on longitudinal studies to view whether the level of participation translates into better proficiency and the rate of that acquisition.

\section{References}

Abdul Halim Mohammad. (2009). Tahap komunikasi dalam bahasa Arab dalam kalangan pelajar Sarjana Muda Bahasa Arab di IPTA Malaysia. JIAE: Journal of Islamic and Arabic Education, 1 (1), 1-14. Retrieved from http://journalarticle.ukm.my/761/

Awatif, Ku Fatahiyah, \& Hairun. (2014). Kaedah pengajaran dan pembelajaran kemahiran mendengar dan bertutur bahasa Arab di IPT. The Journal Of Sultan Alauddin Sulaiman Shah. Retrieved from https://www.researchgate.net/publication/328928416_KAEDAH_PP_KEMAHIRAN MENDENGAR_DAN_BERTUTUR_BA_DI_IPT_MALAYSIA

Azman, Goh. (2010). Situasi pembelajaran bahasa asing di institut pengajian tinggi : perbandingan antara Bahasa Arab, Bahasa Mandarin dan Bahasa Perancis. AJTLHE: ASEAN Journal of Teaching and Learning in Higher Education, 2 (2), 9-21. Retrieved from http://journalarticle.ukm.my/1498/

Celce Murcia. (1989). The teaching of ESL pronunciation in Universiti Teknologi Mara Terengganu Kampus Dungun: A study of instructors' beliefs and practices. Retrieved from https://lib.iium.edu.my/mom/services/mom/document/getFile/31Xx5qJiWA1LHGhTE MRChUgd95LMSs7g20070705151517843

Colley, Bilics, \& Lerch. (2012). The effects of student reflection on academic performance and motivation. Sage Journals. Retrieved from https://journals.sagepub.com/doi/full/10.1177/2158244017733790

Maskanah, Badri, \& Mohd Feham. (2013). Students' perception of an Arabic language course in humanities degree programmes at the International Islamic University Malaysia. World Applied Sciences Journal 21. Retrieved from http://irep.iium.edu.my/30136/ 
Volume 3 Issue 10 (September 2021) PP. 74-85

DOI: 10.35631/IJMOE.310006

McCormick, Dimmitt, \& Sullivan. (2013). Metacognition, learning and instruction. Sage Journals. Retrieved from

https://www.researchgate.net/publication/270570027_Metacognition_Learnin g_and_Instruction

Mohamad Zasfirul Zainal Abidin. (2010). The proficiency and perceptions of English among top management staff in Malaysia. Retrieved from https://lib.iium.edu.my/mom/services/mom/document/getFile/f4gvVEJ9ZdBTvIYTlVB s60XjWzZQEIyX20110323090538406

Mohd Shahrizal, Nurkhamimi, \& Muhammad Sabri. (2017). Persepsi pelajar bukan muslim terhadap pembelajaran bahasa Arab. ISLAMIYYAT 39 (1), 29 - 37. Retrieved from https://www.researchgate.net/publication/321938733_Persepsi_Pelajar_Bukan_Mu slim_Terhadap_Pembelajaran_Bahasa_Arab

Nadwah, Nadhilah. (2014). Permasalahan pertuturan dalam bahasa Arab sebagai bahasa kedua. GEMA: Online Journal of Language Studies, 14 (1), 117-133. Retrieved from http://journalarticle.ukm.my/7003/

Robles. (2012). Executive perceptions of the top 10 soft skills needed in today's workplace. Sage Journal. Retrieved from https://journals.sagepub.com/doi/abs/10.1177/1080569912460400

Rosnih, Mohd Fauzi, Shaferul, \& Amizan. (2013). Aktiviti pengajaran kemahiran bertutur bahasa Arab dalam kalangan jurulatih debat. Gema Online. Journal of Language Studies, 13 (2). Retrieved from https://ejournal.ukm.my/gema/article/view/3308

Rusche, Jason. (2011). The effects of student reflection on academic performance and motivation. Sage Journals. Retrieved from https://journals.sagepub.com/doi/full/10.1177/2158244017733790

Stapa, Tg Nor Rizan, Rosniah, \& Saadiyah. (2008). Workplace written literacy and its effect on the curriculum. GEMA Online Journal of Language Studies 23 Volume 8(1) 2008. Retrieved from https://www.researchgate.net/publication/228892713_Workplace_Written_Literacy _And_Its_Effect_On_The_Curriculum

Sueraya, Ismail, Arifin, \& Ismaiel Hassanein. (2010). Understanding Arabic-speaking skill learning strategies among selected Malay learners: A case-study at the International Islamic University Malaysia (IIUM). Contemporary Issues in Education Research (CIER) 3 (8), 9. Retrieved from https://www.researchgate.net/publication/298332082_Understanding_ArabicSpeaking_Skill_Learning_Strategies_Among_Selected_Malay_Learners_A_CaseStudy_At_The_International_Islamic_University_Malaysia_IIUM

Yancey. (1998). Reflection in the writing classroom. Digital Commons@USU. Retrieved from https://digitalcommons.usu.edu/usupress_pubs/120/ 